The Tongde Picritic Dikes in the Western Yangtze Block: Evidence for Ca. 800-Ma Mantle Plume Magmatism in South China during the Breakup of Rodinia

Author(s): Xian-Hua Li, Wei-Guang Zhu, Hong Zhong, Xuan-Ce Wang, De-Feng He, Zhong-Jie Bai, Feng Liu

Reviewed work(s):

Source: The Journal of Geology, Vol. 118, No. 5 (September 2010), pp. 509-522

Published by: The University of Chicago Press

Stable URL: http://www.jstor.org/stable/10.1086/655113

Accessed: 02/02/2012 00:32

Your use of the JSTOR archive indicates your acceptance of the Terms \& Conditions of Use, available at http://www.jstor.org/page/info/about/policies/terms.jsp

JSTOR is a not-for-profit service that helps scholars, researchers, and students discover, use, and build upon a wide range of content in a trusted digital archive. We use information technology and tools to increase productivity and facilitate new forms of scholarship. For more information about JSTOR, please contact support@jstor.org. 


\title{
The Tongde Picritic Dikes in the Western Yangtze Block: Evidence for Ca. 800-Ma Mantle Plume Magmatism in South China during the Breakup of Rodinia
}

\author{
Xian-Hua Li, Wei-Guang Zhu, ${ }^{1,2}$ Hong Zhong, ${ }^{1}$ Xuan-Ce Wang, \\ De-Feng He, ${ }^{1}$ Zhong-Jie Bai, ${ }^{1}$ and Feng Liu ${ }^{3}$

\begin{abstract}
State Key Laboratory of Lithospheric Evolution, Institute of Geology and Geophysics, Chinese Academy of Sciences, Beijing 100029, China.

(e-mail: lixh@gig.ac.cn)
\end{abstract}

\begin{abstract}
A B S T R A C T
Secondary ion mass spectroscopy U-Pb zircon ages and mineralogical, geochemical, and Nd isotopic data are reported for the Tongde picritic dikes in the Yanbian area of the western Yangtze Block, South China. The picritic dikes, which intruded in the ca. 820-Ma Tongde complex, are dated at $796 \pm 5 \mathrm{Ma}$. Most of the picritic rocks are highly porphyritic (ca. 15-35 vol\% phenocrysts) with dominant olivine (Fo = 82-92) phenocrysts that are high in CaO (up to 0.43 wt $\%$ ), $\mathrm{Cr}_{2} \mathrm{O}_{3}$, and Ni. All the studied rocks are high-Ti and alkaline in composition and exhibit light rare earth elementenriched and "humped" incompatible trace-element patterns, similar to the alkaline basalts within the ocean islands and continental rifts. Variably high $\varepsilon_{\mathrm{Nd}}(T)$ values between +6.9 and +8.7 indicate that these rocks were derived from an asthenospheric mantle source with inappreciable crustal contamination. Geochemical modeling suggests a primary melt of $22.7 \% \mathrm{MgO}$ for batch melting and $21.4 \% \mathrm{MgO}$ for fractional melting. The high $\mathrm{MgO}$ content in the modeled primary magmas implies a minimum melt temperature of $>1400^{\circ} \mathrm{C}$ and a mantle potential temperature of $1600^{\circ}-$ $1620^{\circ} \mathrm{C}$. The Tongde picritic dikes were therefore generated by melting of an anomalously hot mantle source with a potential temperature ca. $200^{\circ} \mathrm{C}$ higher than that of the ambient mid-ocean ridge basalt-source mantle, similar to that of modern mantle plumes. Thus, the Tongde picritic dikes provide solid petrological evidence for the proposed Neoproterozoic mantle plume that led to the breakup of the supercontinent Rodinia.
\end{abstract}

Online enhancements: appendix tables and figures.

\section{Introduction}

South China, including the Yangtze Block to the northwest and the Cathaysia Block to the southeast, retains some of the best-preserved 830-750Ma magmatic and sedimentary records in the world (Li et al. 1999, 2003c; Wang and Li 2003). In recent years, a number of studies have documented the Neoproterozoic igneous rocks along the western

Manuscript received October 12, 2009; accepted May 11, 2010 .

${ }^{1}$ State Key Laboratory of Ore Deposit Geochemistry, Institute of Geochemistry, Chinese Academy of Sciences, Guiyang 550002, China.

${ }^{2}$ Key Laboratory of Isotope Geochronology and Geochemistry, Guangzhou Institute of Geochemistry, Chinese Academy of Sciences, Guangzhou 510640, China. China. margin of the Yangtze Block, but the genesis and tectonic implications of these rocks remain a subject of debate, as outlined by two competing models. Li and coauthors suggested that the rocks older than $860 \mathrm{Ma}$ (most likely $\geq 900 \mathrm{Ma}$ ) were formed before or during the Sibao Orogeny associated with the assembly of the supercontinent Rodinia, whereas the 830-740-Ma rocks were anorogenic products related to superplume activity during the breakup of Rodinia (Li et al. 2002a, 2003a, 2003c, 2006; Lin et al. 2007; Zhu et al. 2008). Zhou and others, however, considered all these Neoproterozoic rocks to have been formed in a roughly northsouth-trending (present-day coordinates) active continental margin (Zhou et al. 2002b, 2006a, 2006b; Zhao and Zhou 2007; Sun et al. 2007, 2008).

[The Journal of Geology, 2010, volume 118, p. 509-522] () 2010 by The University of Chicago. All rights reserved. 0022-1376/2010/11805-0004\$15.00. DOI: 10.1086/655113 
Picrites, with $\mathrm{MgO}$ content of $12-18 \mathrm{wt} \%$, occur in different tectonic settings (Le Bas 2000; Tsikouras et al. 2008). Primary picritic melts require higher degrees of partial melting and higher temperature than basaltic melts (e.g., Herzberg and O'Hara 1998). Picritic melts are generally associated with abnormally hot mantle, as in many large igneous provinces (LIPs) generated by upwelling of mantle plume heads (Thompson et al. 2001; Zhang et al. 2006). A number of picritic dikes that intruded the ca. 820-Ma Tongde complex in the Yanbian area of the southwestern Yangtze Block were identified in this study. Comprehensive investigations in secondary ion mass spectroscopy (SIMS) U-Pb zircon age, mineralogy, geochemistry, and $\mathrm{Sm}-\mathrm{Nd}$ isotopes for these picritic dikes were conducted with the aims of (1) determining the crystallization age of the dikes, (2) constraining the origin and petrogenesis of the rocks, and (3) shedding new light on the Neoproterozoic tectonic evolution along the western margin of the Yangtze Block.

\section{Geological Background}

The Kangding-Panzhihua area is located on the western margin of the Yangtze Block of South China, to the east of the Songpan-Ganzi orogenic belt (fig. 1a). The basement rocks in this area mainly consist of late Mesoproterozoic to earliest Neoproterozoic metasedimentary rocks interbedded with felsic and mafic metavolcanic rocks of the Kunyang, Huili, and Yanbian groups (Li et al. 2002b, 2006; Greentree et al. 2006). These rocks are overlain by a thick sequence $(>9 \mathrm{~km})$ of Neoproterozoic (850-540-Ma) to Permian strata composed of clastic, carbonate, and metavolcanic rocks, including the middle Neoproterozoic bimodal volcanic rocks and clastic rocks within the Suxiong and Kaijianqiao formations (Li et al. 2002a). The Suxiong and Kaijianqiao formations unconformably overlie the folded Huili Group. The late Neoproterozoic clastic rocks and phosphorus-bearing carbonate rocks occur within the Guanyinya and Dengying formations (Cong 1988, p. 267-314; SBGMR 1991).

There are three major Precambrian rock units in the Yanbian area (fig. 1b): (1) metavolcanic rocks and schists of the Yanbian Group, (2) Neoproterozoic igneous rocks that intruded the Yanbian Group, and (3) upper Neoproterozoic successions that unconformably overlie the Yanbian Group and the intruding igneous rocks. The east-west Yanbian Group ( $\geq 900 \mathrm{Ma}$ ) is strongly deformed and variably metamorphosed (Li et al. 2006) and consists of four formations: from bottom to top, the Huangtian, Yu- men, Xiaoping, and Zhaigu formations (SBGMR 1991). The Huangtian Formation mainly contains metabasaltic pillow lavas interbedded with several chert and schist layers. The Yumen Formation consists of carbonaceous slate with siltstone in its lower part and carbonaceous and tuffaceous slate in its upper part. The Xiaoping Formation is composed of slate, sandstone, and conglomerate. The Zhaigu Formation comprises slate and conglomerate (SBG 1972; SBGMR 1991; Sun and Vuagnat 1992).

Mid-Neoproterozoic granitoids, mafic-ultramafic intrusive bodies, and mafic dikes are widespread throughout the Yanbian area (fig. 1b). They include the ca. 860-Ma Guandaoshan dioritic pluton (Li et al. 2003b), the ca. 820-Ma Tongde complex (Sinclair 2001), the ca. 825-820-Ma Gaojiacun and Lengshuiqing mafic-ultramafic plutons (Zhou et al. 2006a; Zhu et al. 2006, 2007), and the ca. 790-760Ma mafic dikes to the north of the Gaojiacun and Lengshuiqing plutons (Zhu et al. 2008). All these rocks intrude into the Yanbian Group.

Three picritic dikes investigated in this article intruded the Tongde complex (fig. 1b). They strike northwest to northeast and dip to the northeast or southeast with an angle of $\sim 70^{\circ}-80^{\circ}$. The dikes are up to $2 \mathrm{~km}$ long, with a thickness between 30 and $100 \mathrm{~m}$. They are black, phyric picritic dikes, containing abundant (ca. 15-35 vol\%) large phenocrysts of olivine and minor clinopyroxene. The matrix minerals consist mainly of clinopyroxene and plagioclase (fig. 2). Rock-forming minerals comprise olivine ( $15 \%-30 \%$ by volume), clinopyroxene $(30 \%-40 \%)$, plagioclase $(30 \%-40 \%)$, Fe-Ti oxides $(1 \%-2 \%)$, and chromite $(<1 \%)$. Chromite grains are enclosed in olivine, whereas Fe-Ti oxide (magnetite and ilmenite) grains are usually interstitial to olivine and enclosed in clinopyroxene or plagioclase.

\section{Analytical Methods}

Zircon grains from sample TBZ0600 were separated with conventional heavy-liquid and magnetic techniques. Representative zircon grains, together with zircon standards (91500), were handpicked under a binocular microscope, mounted on an epoxy resin disc, and then polished and coated with gold film before SIMS analysis. Zircons were documented with transmitted- and reflected-light micrographs, as well as cathodoluminescence (CL) images, to reveal their external and internal structures. Measurements of $\mathrm{U}, \mathrm{Th}$, and $\mathrm{Pb}$ for zircon grains were conducted with the Cameca IMS-1280 secondary ion mass spectroscope at the Institute of Geology and Geophysics at the Chinese Academy of Sci- 


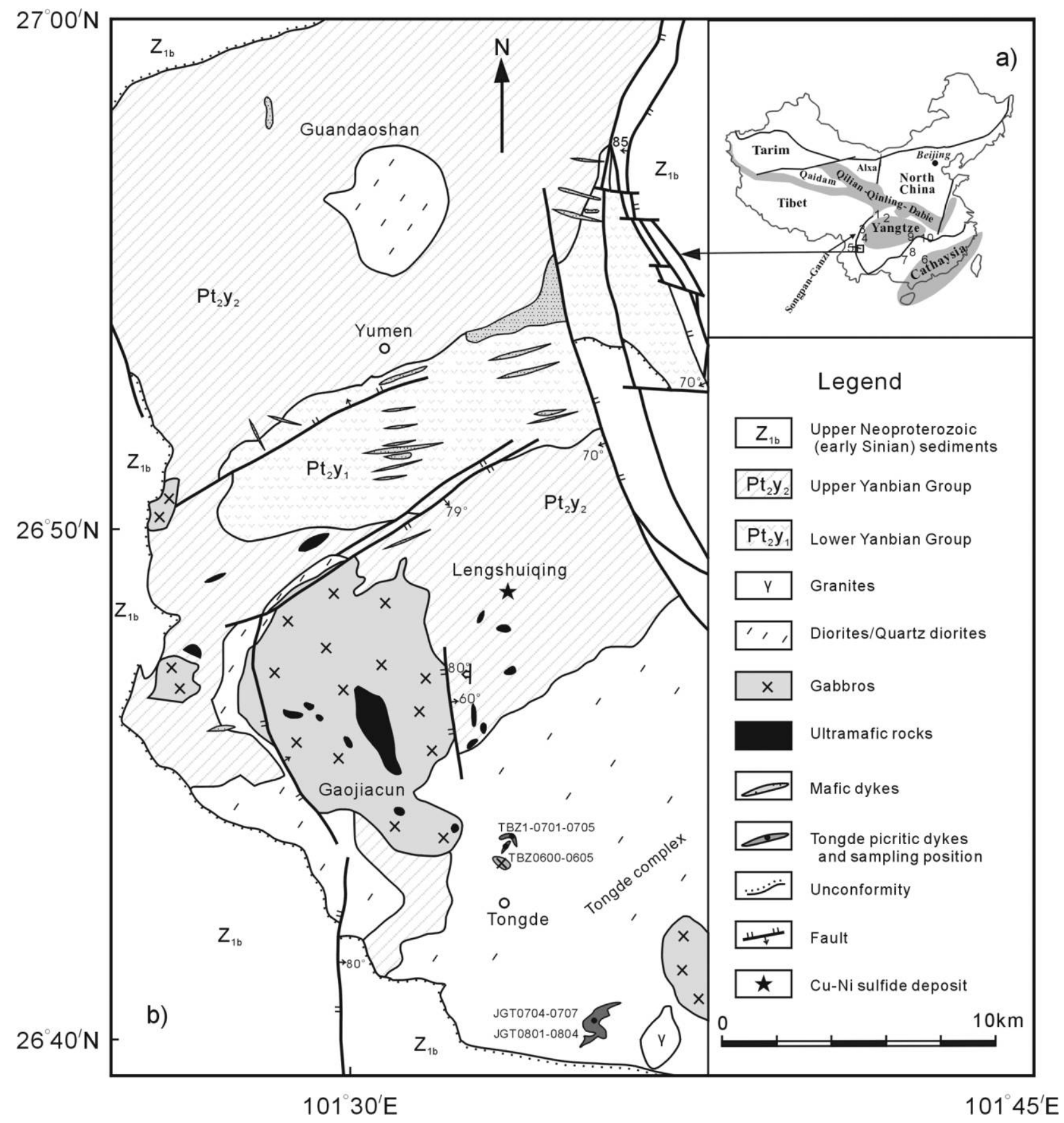

Figure 1. a, Location of the Yanbian area of the western Yangtze Block in relation to China's major tectonic units. Numbers represent 825-760-Ma volcanic rocks and mafic-ultramafic intrusions along the margin of the Yangtze Block: 1 = Bikou flood basalts (825-810 Ma; Wang et al. 2008), 2 = Tiechuanshan flood basalts and associated dacites/ rhyolites (817 $\pm 5 \mathrm{Ma}$; Ling et al. 2003), 3 = Kangding mafic dike swarm (790-760 Ma; Li et al. $2003 c$; Lin et al. 2007), 4 = Suxiong bimodal basalts-dacites/rhyolites (810-800 Ma; Li et al. 2002a), 5 = Gaojiacun mafic-ultramafic complex (825 $\pm 12 \mathrm{Ma}$; Zhu et al. 2008) and Yanbian mafic sills/dikes (790-760 Ma; Zhu et al. 2008), $6=$ Yingyangguan spilite-keratophyre (819 $\pm 11 \mathrm{Ma}$; Zhou et al. 2002a), 7 = Guibei mafic dikes and sills (828 $\pm 7 \mathrm{Ma}$; Li et al. 1999), 8 = Guibei spilites and gabbros ( 760 Ma; Zhou et al. 2007), $9=$ Xiangxi diabases ( 760 Ma; Zhou et al. 2007), and 10 = Yiyang komatiitc basalts $(823 \pm 6 \mathrm{Ma}$; Wang et al. 2007). b, Simplified Precambrian geological map of the Yanbian area of the western Yangtze Block, South China (modified after SBG 1972 and RGTCCT 2000). 

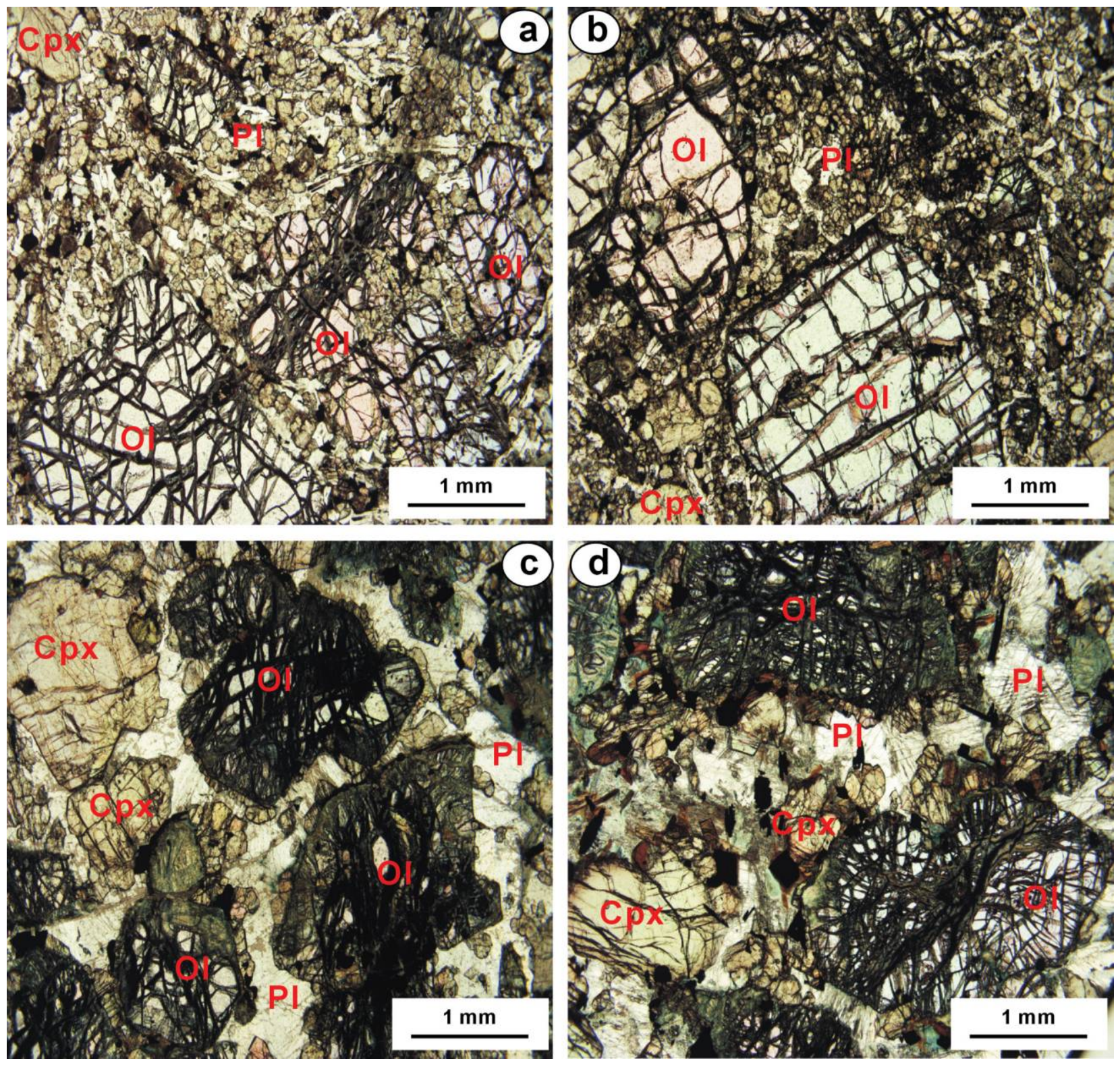

Figure 2. Photomicrographs of representative Tongde picritic dikes in the Yanbian area: samples TBZ1-0703 $(a)$, TBZ0600 $(b)$, JGT0704 $(c)$, and JGT0804 $(d)$. Cpx = clinopyroxene, $\mathrm{Ol}=$ olivine, $\mathrm{Pl}=$ plagioclase.

ences (CAS) in Beijing. U-Th- $\mathrm{Pb}$ ratios and absolute abundances were determined relative to the standard zircon 91500 (Wiedenbeck et al. 1995). The standard analyses were interspersed with those of unknown grains according to operating and data processing procedures described by Li et al. (2009). The mass resolution used to measure $\mathrm{Pb} / \mathrm{Pb}$ and $\mathrm{Pb} / \mathrm{U}$ isotopic ratios was 5400 during the analyses. Nonradiogenic ${ }^{204} \mathrm{~Pb}$ was used to correct measured compositions for common $\mathrm{Pb}$. Corrections were sufficiently small as to be insensitive to the choice of common- $\mathrm{Pb}$ composition. An average of presentday crustal composition (Stacey and Kramers 1975) was used for common $\mathrm{Pb}$, under the assumption that the common $\mathrm{Pb}$ is largely surface contamination introduced during sample preparation.

Chemical compositions of olivine and clinopyroxene were determined by wavelength-dispersive $\mathrm{x}$-ray emission spectrometry using an EPMA-1600 electron microprobe at the State Key Laboratory of Ore Deposit Geochemistry (SKLOG) at the Institute of Geochemistry, CAS (IGCAS). Major ele- 

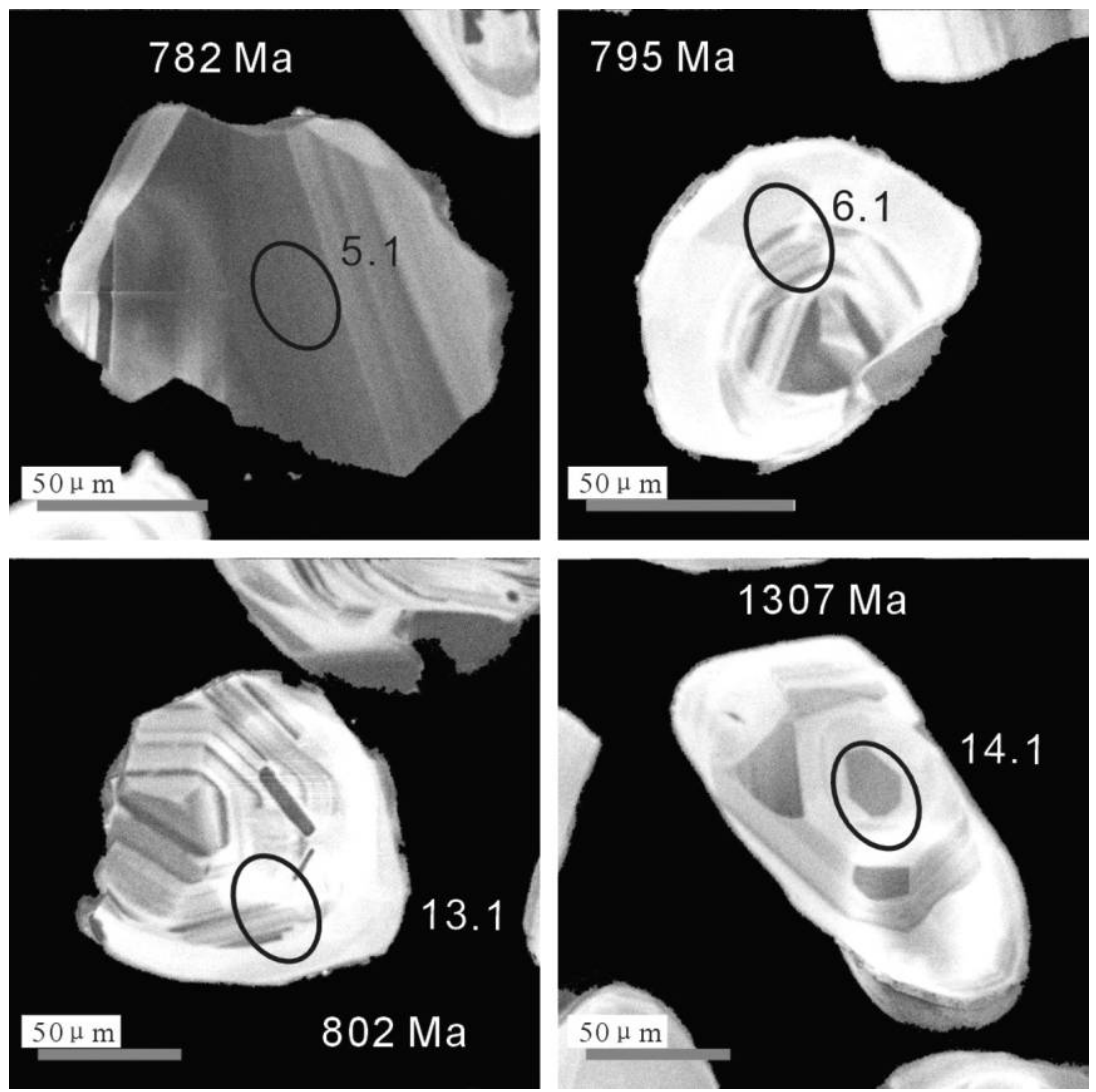

Figure 3. Representative cathodoluminescence images of zircon grains for sample TBZ0600 from the Tongde picritic dikes in the Yanbian area.

ments were analyzed with a PANalytical Axiosadvance $\mathrm{x}$-ray fluorescence spectrometer at the SKLOG, IGCAS, using fused lithium-tetraborate glass pellets. Analytical precision, as determined on the Chinese national standard GSR-3, was generally $1 \%-5 \%$. Trace elements were analyzed with a Perkin-Elmer ELAN-DRC-e ICP-MS at the SKLOG, IGCAS. Powdered samples of $50 \mathrm{mg}$ were dissolved in high-pressure Teflon bombs using a HF $+\mathrm{HNO}_{3}$ (1:1 ratio) mixture for $48 \mathrm{~h}$ at $\sim 195^{\circ} \mathrm{C}$. $\mathrm{Rh}$ was used as an internal standard to monitor signal drift during counting (Qi et al. 2000). The international standards GBPG-1 and OU-6 and the Chinese national standard GSR-3 were used for analytical quality control, with the precision generally better than $5 \%$.

Samples for Sm-Nd isotopic analysis were spiked and dissolved in Teflon bombs with HF + $\mathrm{HNO}_{3}$ (2:1 ratio) acid and separated by conventional cation-exchange techniques. The isotopic measurements were performed on a Finnigan MAT 262 thermal ionization mass spectrometer at the Institute of Geology and Geophysics, CAS.
The measured ${ }^{143} \mathrm{Nd} /{ }^{144} \mathrm{Nd}$ ratios were normalized to ${ }^{146} \mathrm{Nd} /{ }^{144} \mathrm{Nd}=0.7219$. The ${ }^{143} \mathrm{Nd} /{ }^{144} \mathrm{Nd}$ ratios of the USGS standard rock BCR-1 and La Jolla Nd standard solution determined during this study were $0.512624 \pm 0.000011(2 \sigma)$ and $0.511852 \pm$ $0.000006(2 \sigma)$, respectively.

\section{Results}

U-Pb Zircon Geochronology. Zircon grains in sample TBZ0600 $\left(26^{\circ} 44^{\prime} 04.2^{\prime \prime} \mathrm{N}, 101^{\circ} 33^{\prime} 21.2^{\prime \prime} \mathrm{E}\right)$ are mostly euhedral and up to $50-150 \mu \mathrm{m}$ long, with length-to-width ratios between $1: 1$ and $2: 1$. Most zircons are clear, prismatic grains with simple internal growth zoning (fig. 3). Fourteen analyses for this sample were obtained from 14 grains during a single analytical session (table A1, available in the online edition or from the Journal of Geology office). Measured U concentrations vary from 36 to $581 \mathrm{ppm}$ and measured Th concentrations from 20 to $357 \mathrm{ppm}$, with $\mathrm{Th} / \mathrm{U}$ ratios of $0.42-1.55$. Thirteen of the 14 measured ${ }^{206} \mathrm{~Pb} /{ }^{238} \mathrm{U}$ ages are in good agreement within analytical errors, yielding a 
weighted mean age of $796 \pm 5 \mathrm{Ma}(95 \%$ confidence interval; fig. 4). This age is considered to be the best estimate of the crystallization age for sample TBZ0600. Spot 14.1 yields apparently older U-Pb and $\mathrm{Pb} / \mathrm{Pb}$ dates of ca. 1.3 Ga, interpreted as the age of a xenocrystal.

Mineral Chemistry. Representative compositions of olivine and clinopyroxene from the Tongde picritic dikes are listed in tables A4 and A5, respectively, available in the online edition or from the Journal of Geology office.

The forsterite (Fo $=100 \times \mathrm{Mg} /(\mathrm{Mg}+\mathrm{Fe}), \mathrm{mol} \%$ ) content of olivine from the Tongde picritic dikes varies from 81.6 to 92.3 . The Mg-rich olivine crystals are visually indistinguishable from those with Fo $<90$. Most olivine crystals are characterized by relatively high $\mathrm{NiO}(0.25 \%-0.54 \%$, i.e., $1981-4322$ ppm Ni), $\mathrm{CaO}(0.11 \%-0.43 \%)$, and $\mathrm{Cr}_{2} \mathrm{O}_{3}(0.013 \%-$ $0.36 \%$ ) contents (table A4).

Clinopyroxenes in the picritic rocks are relatively high in $\mathrm{TiO}_{2}(0.70-2.23 \mathrm{wt} \%), \mathrm{Cr}_{2} \mathrm{O}_{3}(0.13-$ $1.31 \mathrm{wt} \%)$, and $\mathrm{MgO}(13.24-17.68 \mathrm{wt} \%)$, with $\mathrm{Mg}$ numbers $(\mathrm{Mg} \#)$ between 75.5 and 87.7. The clinopyroxenes are augite, with a composition range of $\mathrm{Wo}_{36-46} \mathrm{En}_{41-52} \mathrm{Fs}_{7-14}$ (table A5).
Whole-Rock Geochemistry. Major- and trace-element data for the Tongde picritic dikes are presented in table A2, available in the online edition or from the Journal of Geology office. All the samples in this study are relatively fresh to moderately altered (fig. 2), as suggested by variable loss-onignition (LOI) values of $1.24 \%-6.43 \%$. Most of the olivine-rich samples have the highest LOI values, illustrated by the positive corrections between LOI and $\mathrm{MgO}$ contents (fig. 5), possibly because of varying degrees of serpentinization (fig. 2).

The major-element oxides were recalculated to $100 \%$ on a volatile-free base. The picritic dikes are fairly homogeneous in major-element composition, with relatively low $\mathrm{SiO}_{2}(43.8 \%-46.0 \%)$ and total alkalis $\left(\mathrm{Na}_{2} \mathrm{O}+\mathrm{K}_{2} \mathrm{O} \leq 2.0 \%\right)$ but high $\mathrm{MgO}$ $(17.5 \%-27.4 \%), \mathrm{Fe}_{2} \mathrm{O}_{3}(13.1 \%-14.1 \%), \mathrm{TiO}_{2}(1.3 \%-$ $2.1 \%)$, and $\mathrm{CaO}(6.2 \%-9.6 \%)$, a $\mathrm{Mg \#}$ of $72.3-80.3$, and $\mathrm{Fe} / \mathrm{Mn}$ ratios of $75.5-85.6$ (table A2). These samples are also characterized by high Cr (14491859 ppm) and Ni (807-1260 ppm; table A2; fig. 5). In the Fenner diagrams (fig. 5), $\mathrm{SiO}_{2}, \mathrm{TiO}_{2}, \mathrm{CaO}$, $\mathrm{Al}_{2} \mathrm{O}_{3}$, and $\left(\mathrm{Na}_{2} \mathrm{O}+\mathrm{K}_{2} \mathrm{O}\right)$ contents significantly increase, whereas Ni significantly decreases with decreasing $\mathrm{MgO}$ content. Meanwhile, the $\mathrm{Fe}_{2} \mathrm{O}_{3}$ and

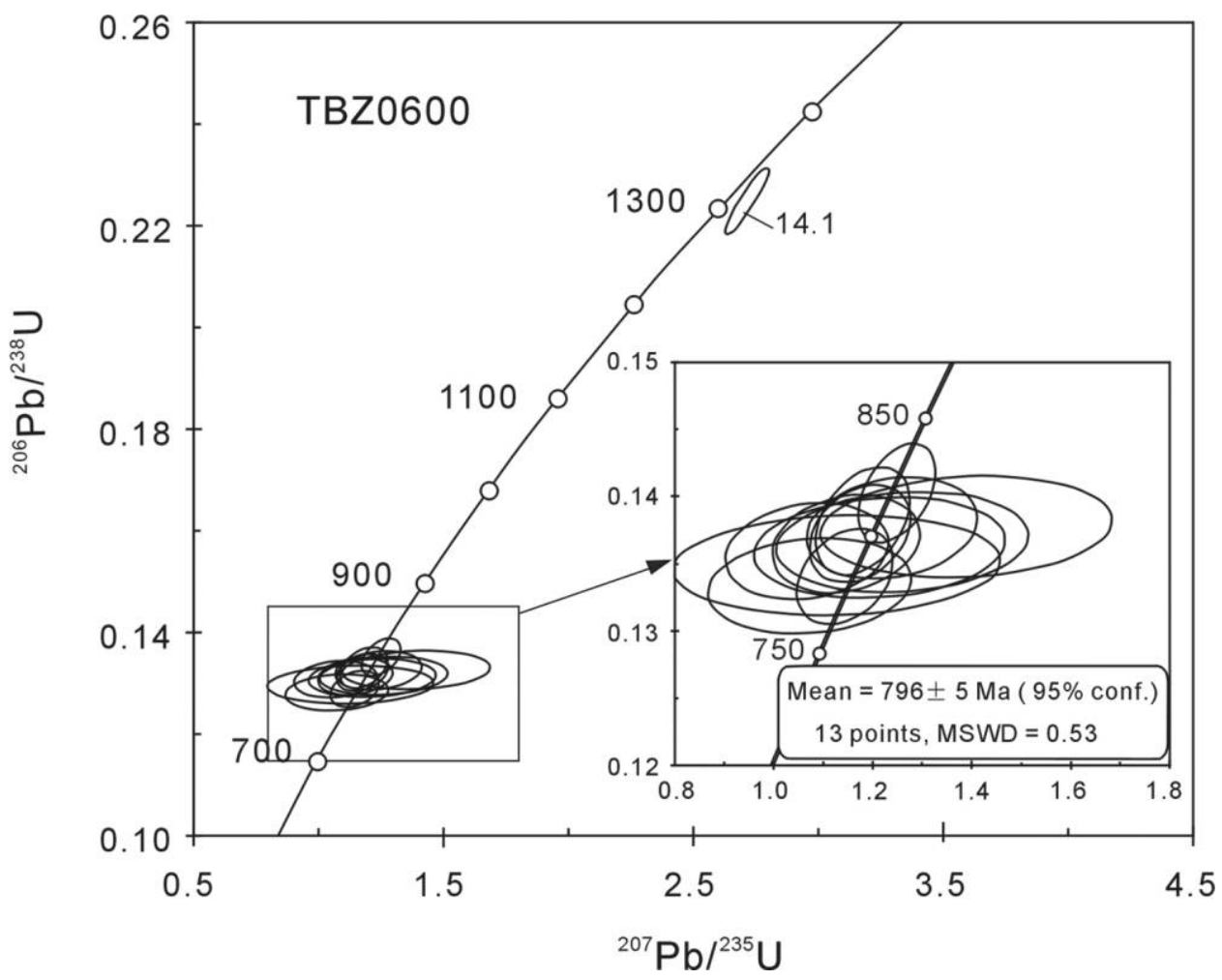

Figure 4. Secondary ion mass spectroscopy zircon U-Pb concordia diagrams for sample TBZ0600 from the Tongde picritic dikes in the Yanbian area. 

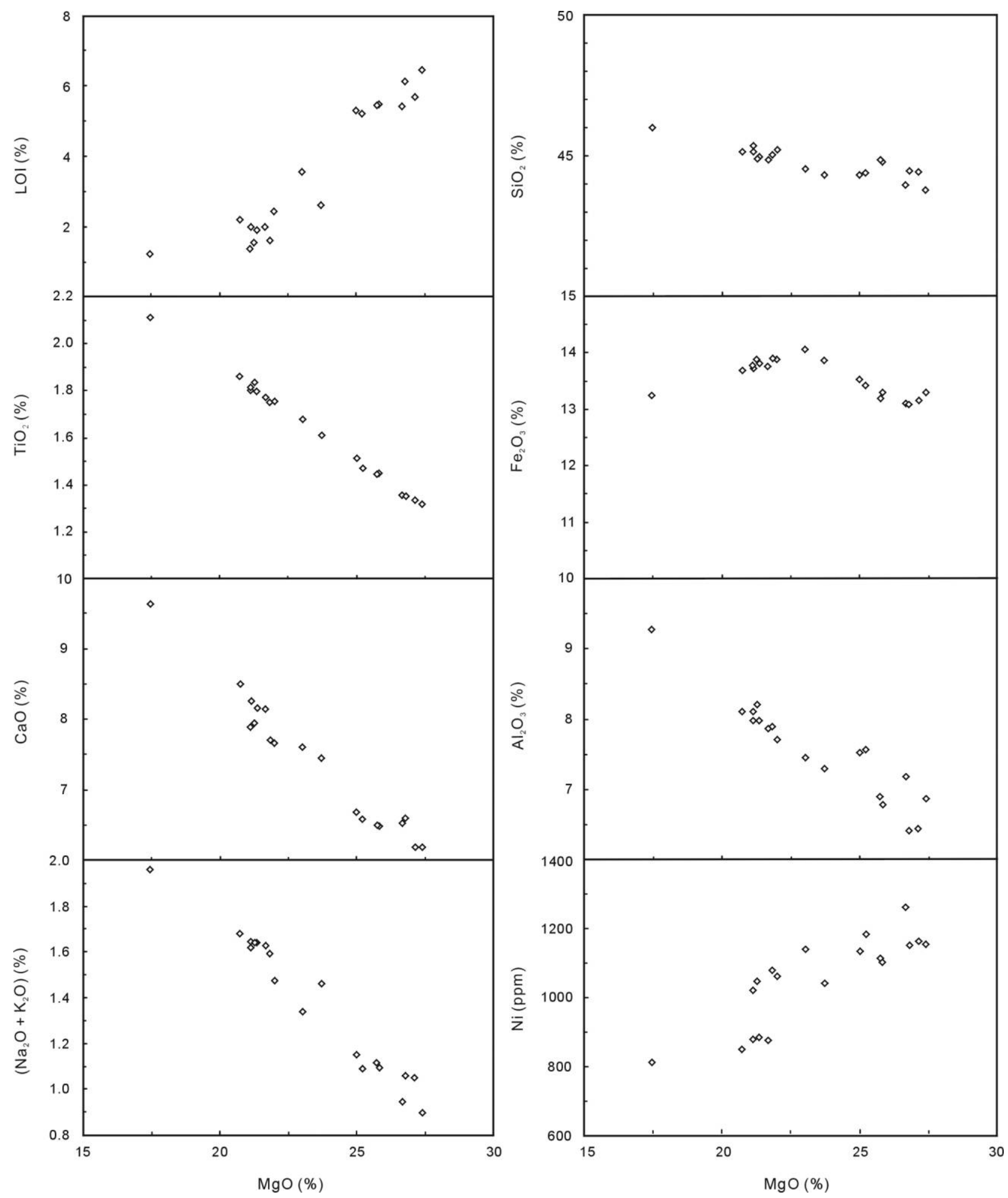

Figure 5. Fenner diagrams for the Tongde picritic dikes in the Yanbian area. 
Cr contents (not shown) of the Tongde picritic dikes exhibit a fairly constant or slightly increasing trend with decreasing $\mathrm{MgO}$ content (fig. 5). These rocks have $\mathrm{Nb} / \mathrm{Y}$ ratios of $0.72-0.94$, plotting exclusively into the alkaline-basalt field on the $\mathrm{Nb} / Y$-versus$\mathrm{Zr} / \mathrm{TiO}_{2}$ diagram of Winchester and Floyd (1976; fig. Ala, available in the online edition or from the Journal of Geology office). In addition, all the picritic dikes have $\mathrm{Ti} / \mathrm{Y}$ ratios of $>500$ (fig. A $1 b$ ), similar to those of high-Ti basaltic rocks (Peate et al. 1992; Xu et al. 2001).

The Tongde picritic dikes have total rare earth element (REE) contents of 54-111 ppm and exhibit uniform chondrite-normalized light-REE-enriched patterns (fig. 6a), with $\mathrm{La}_{\mathrm{N}}=27-58,(\mathrm{La} / \mathrm{Yb})_{\mathrm{N}}=$ 6.7-9.9 (the subscript $\mathrm{N}$ denotes chondritenormalized), and insignificant $\mathrm{Eu}$ anomalies $\left(\mathrm{Eu} / \mathrm{Eu}^{*}=0.94-1.16\right)$. In a primitive-mantlenormalized spidergram (Sun and McDonough 1989|, they show "humped" patterns characterized by variable enrichment in all incompatible elements (fig. 6b). No visible depletions in $\mathrm{Nb}$, $\mathrm{Ta}$, and Ti relative to the neighboring elements $(\mathrm{Nb} / \mathrm{La}=$ 0.91-1.11, $\mathrm{Nb} / \mathrm{Th}=8.17-10.12$ ) are observed. Most samples display striking negative $\mathrm{Pb}$ anomalies relative to the neighboring elements (fig. 6), resembling the intraplate alkali basaltic rocks in continental flood basalt (CFB) and ocean island basalt (OIB) provinces (Sun and McDonough 1989).

Sm-Nd Isotopes. Sm-Nd isotopic data for the Tongde picritic dikes are presented in table A3, available in the online edition or from the Journal of Geology office. The rocks have fairly constant ${ }^{147} \mathrm{Sm} /{ }^{144} \mathrm{Nd}$ ratios between 0.1415 and 0.1514 and ${ }^{143} \mathrm{Nd} /{ }^{144} \mathrm{Nd}$ ratios between 0.512709 and 0.512821 , corresponding to initial $\varepsilon_{\mathrm{Nd}}(T)(T=795 \mathrm{Ma})$ values between 6.9 and 8.7. These highly radiogenic $\mathrm{Nd}$ isotopic compositions suggest that the parental magmas of the Tongde picritic dikes were derived from a time-integrated depleted-mantle source.

\section{Discussion}

Crystal Accumulation and Crustal Contamination. The Tongde picritic dikes are very high in $\mathrm{MgO}(17.5 \%-27.4 \%)$ and low in $\mathrm{SiO}_{2}, \mathrm{Na}_{2} \mathrm{O}$, and $\mathrm{K}_{2} \mathrm{O} . \mathrm{MgO}$ and $\mathrm{Ni}$ increase with decreasing $\mathrm{SiO}_{2}$, exhibiting a compositional trend dominantly controlled by olivine accumulation (fig. 5). In the Pearce element ratio diagram of $(\mathrm{Mg}+\mathrm{Fe}) / \mathrm{Al}$ versus Si/Al (fig. A2, available in the online edition or from the Journal of Geology office), the data form a linear trend with a slope of 2.06, close to the ideal index of 2.0 for crystal addition/separation of olivine (Russell and Nicholls 1988). However, $\mathrm{Fe}_{2} \mathrm{O}_{3}$ and $\mathrm{Cr}$ are nearly constant over a wide range of $\mathrm{MgO}$, indicating little clinopyroxene accumulation/separation. Negative correlations of $\mathrm{Al}_{2} \mathrm{O}_{3}$, $\mathrm{CaO}$, and $\left(\mathrm{Na}_{2} \mathrm{O}+\mathrm{K}_{2} \mathrm{O}\right)$ versus $\mathrm{MgO}$ (fig. 5) suggest that these rocks underwent insignificant plagioclase fractionation (Pik et al. 1998). The increase of $\mathrm{TiO}_{2}$ with decreasing $\mathrm{MgO}$ indicates that $\mathrm{TiO}_{2}$ was incompatible in the crystallizing phases and thus that titanomagnetite did not appear in the liq-
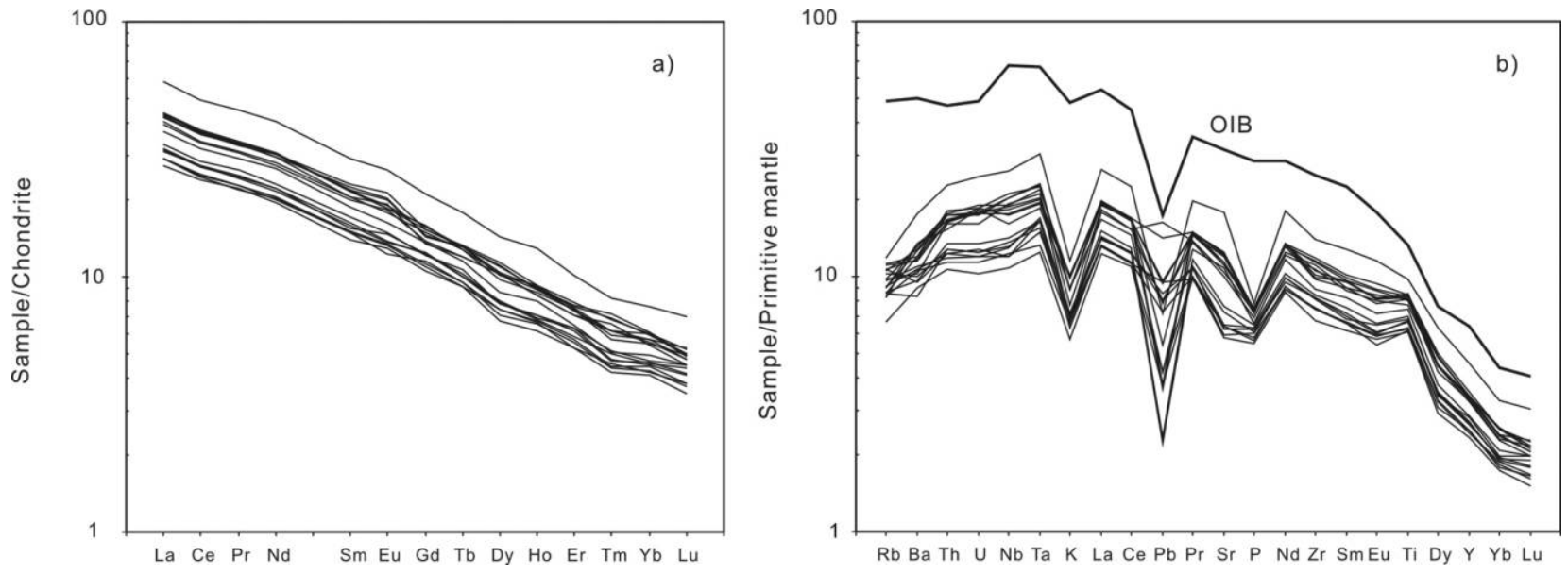

Figure 6. Chondrite-normalized rare earth element patterns $(a)$ and primitive mantle-normalized incompatible traceelement spidergram $(b)$ for the Tongde mafic picritic dikes in the Yanbian area. The normalization values for chondrite are from Boynton (1984). The normalization values for the primitive mantle are from Sun and McDonough (1989). OIB = ocean island basalt. 
uidus of these systems. As a result, chemical variations of the Tongde picritic dikes are dominantly controlled by olivine accumulation.

These rocks are characterized by a lack of clear depletion in $\mathrm{Nb}, \mathrm{Ta}$, and $\mathrm{Ti}$ relative to the neighboring elements in the trace-element spidergram (fig. $6 b$ ) and by highly positive $\varepsilon_{\mathrm{Nd}}(T)$ values between 6.9 and 8.7 (table A3), indicating minimal crustal contamination. There are, however, positive correlations between $\varepsilon_{\mathrm{Nd}}(T)$ and $\mathrm{Nb} / \mathrm{La}$ values (fig. $7 a$ ) and between $\mathrm{Nb} / \mathrm{Th}$ and $\mathrm{Nb} / \mathrm{La}$ ratios (fig.
$7 b$ ), suggesting that the relative enrichment of $\mathrm{La}$ and slight depletion of $\mathrm{Nb}$ and $\mathrm{Ta}$ in these rocks are likely attributable to minor crustal contamination (e.g., Paces and Bell 1989). This is consistent with the elevated $\mathrm{Pb}$ abundance in a few samples (TBZ1-0704, TBZ0602, and JGT0704) and the existence of xenocrytsal zircon (spot 14.1).

Nature of the Parental Magma and Mantle Source Characteristics. The geochemical and $\mathrm{Nd}$ isotopic characteristics of most Tongde dikes are generally similar to those of the alkali basalts derived from

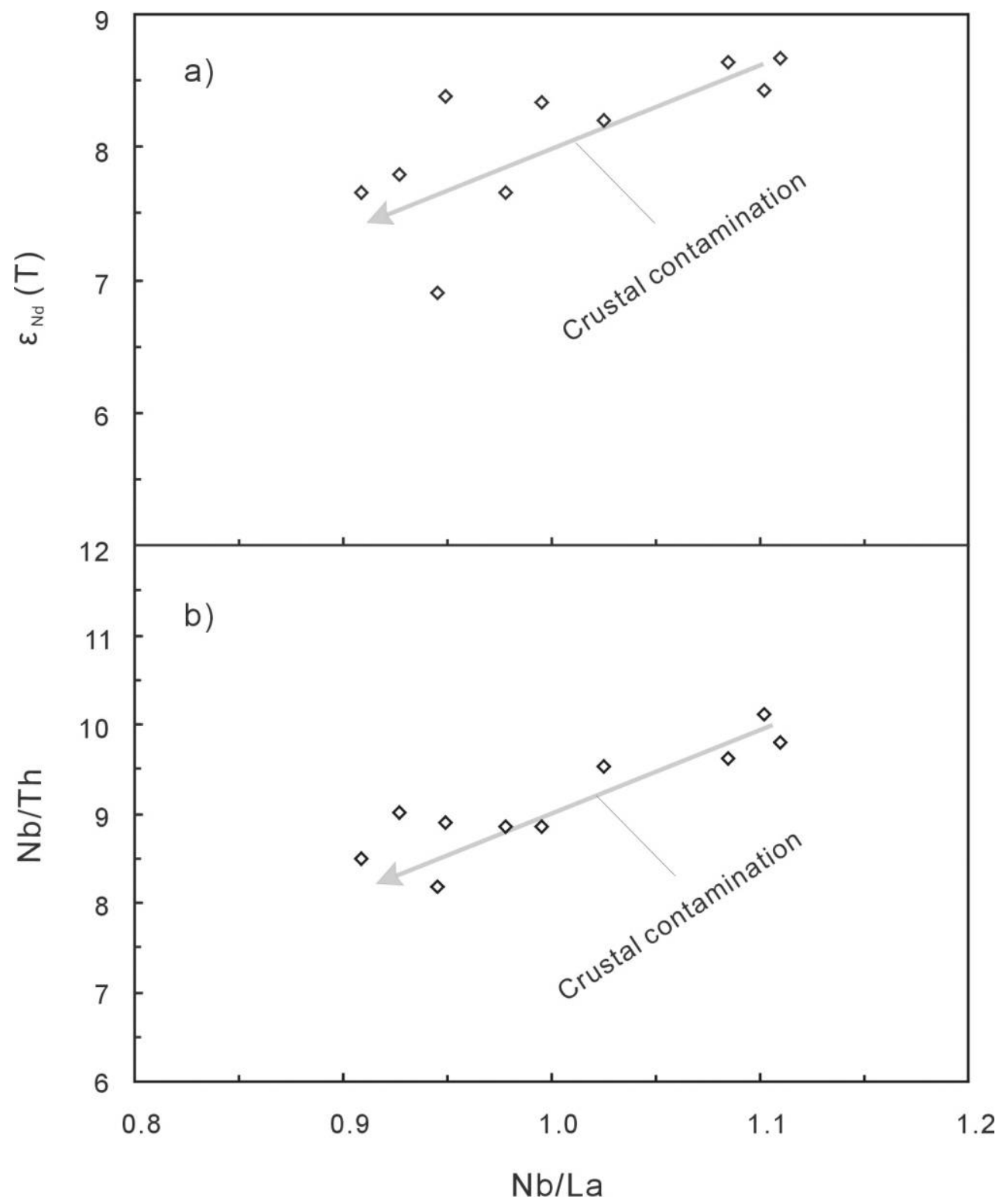

Figure 7. Plots of $\mathrm{Nb} / \mathrm{La}$ versus $\varepsilon_{\mathrm{Nd}}(T)(a)$ and $\mathrm{Nb} / \mathrm{La}$ versus $\mathrm{Nb} / \mathrm{Th}(b)$ for the Tongde picritic dikes in the Yanbian area. 
OIB-like mantle sources within continental rifts (fig. 6), such as the alkaline basalts in the modern East African Rift (Stewart and Rogers 1996; Pik et al. 1999) and the ca. 810-Ma Suxiong alkaline basalts in the Kangding Rift of the western Yangtze Block (Li et al. 2002a). Relatively low abundances of most incompatible trace elements in the Tongde dikes, compared with those in OIBs, are most likely due to dilution by olivine accumulation. Thus, the parental magmas of these picritic dikes were most likely generated by melting of an OIB-like mantle source. Petrographically, these rocks appear to be crystal cumulates (fig. 2), as confirmed by the geochemical data (figs. 5, A2). Before estimating their primary melt, we first considered how the compositions of each sample may have been changed during alteration, as these samples suffered variable degrees of alteration (fig. 5). The least-altered compositions of the dikes were estimated on the basis of correlations between major elements and LOI value. At $\mathrm{LOI}=1 \%$, the least-altered compositions are $\mathrm{SiO}_{2}=45 \%, \quad \mathrm{TiO}_{2}=2 \%, \mathrm{Al}_{2} \mathrm{O}_{3}=8.5 \%$, $\mathrm{Fe}_{2} \mathrm{O}_{3}^{\mathrm{T}}=13 \%, \quad \mathrm{MgO}=20 \%, \quad \mathrm{CaO}=10 \%$, $\mathrm{Na}_{2} \mathrm{O}=1.5 \%$, and $\mathrm{K}_{2} \mathrm{O}=0.35 \%$, similar to the major-element compositions of the least-altered and least-contaminated sample, TBZ0600 $\left(\varepsilon_{\mathrm{Nd}}(T)=8.2\right)$. These compositions were then used as the starting material to calculate the primarymelt composition. A good approach is outlined in Herzberg et al. (2007), in which magma compositions are projected into a mantle-phase diagram. Applying the Herzberg et al. method and assuming the composition of TBZ0600 as an end member, a primary melt of $\sim 45.6 \% \mathrm{SiO}_{2}, \sim 22.7 \% \quad \mathrm{MgO}$, $\sim 11.5 \% \mathrm{FeO}$, and $8.2 \% \mathrm{CaO}$ for batch melting and one of $\sim 45.8 \% \mathrm{SiO}_{2}, \sim 21.4 \% \mathrm{MgO}, \sim 11.7 \% \mathrm{FeO}$, and $8.6 \% \mathrm{CaO}$ for fractional melting were obtained with the PRIMELT2.XLS software (Herzberg and Asimow 2008). On the basis of the methods of Albarède (1992) and Herzberg et al. (2007), the temperature of the primary melt (under anhydrous melting condition) was estimated at $1470^{\circ} \mathrm{C}-$ $1490^{\circ} \mathrm{C}$. Because of the effect of water (Herzberg et al. 2007), the melt temperature would be reduced by $70^{\circ} \mathrm{C}$. Thus, a minimum melt temperature of $>1400^{\circ} \mathrm{C}$ can be reasonably estimated for the Tongde picritic dikes.

The mantle potential temperature $T_{\mathrm{p}}(\mathrm{McKenzie}$ and Bickle 1988), a reference for measuring the thermal state of mantle sources, was estimated at $1600^{\circ}-1620^{\circ} \mathrm{C}$ with the methods of McKenzie and Bickle (1988), Langmuir et al. (1992), Putirka (2005), and Herzberg et al. (2007). Our estimated $T_{\mathrm{p}}$ values imply that the Tongde picritic dikes were derived from an anomalously hot mantle that was ca. $200^{\circ} \mathrm{C}$ hotter than the contemporary ambient mid-ocean ridge basalt (MORB)-source mantle, having a $T_{\mathrm{p}} \approx$ $1350^{\circ}-1450^{\circ} \mathrm{C}$, inferred from the secular Earthcooling model of Pollack (1997).

The Tongde picritic dikes have Mg\#'s of 72.380.3 (table A2), lower than the $88.2 \pm 0.3$ for Hawaiian OIB (Humayun et al. 2004). These rocks show $\mathrm{Fe} / \mathrm{Mn}$ ratios of $75.5-85.6$, which are higher than the $66.9 \pm 1.8$ for Hawaiian OIB (Humayun et al. 2004). Because most of the Fe in the mantle is $\mathrm{Fe}^{2+}(\mathrm{FeO})$ and all of the $\mathrm{Mn}$ is $\mathrm{Mn}^{2+}(\mathrm{MnO}), \mathrm{Fe}$ and $\mathrm{Mn}$ share the same charge and ionic radius and have similar partitioning behavior in magmatic processes (Humayun et al. 2004). Experimental studies of partial melting of pyroxenite and peridotite show that the $\mathrm{Fe} / \mathrm{Mn}$ ratios for pyroxenite melts are higher than those for peridotite melts because clinopyroxene, orthopyroxene, and garnet all have $D(\mathrm{Fe})>D(\mathrm{Mn})$, whereas olivine has $D(\mathrm{Fe})<D(\mathrm{Mn})$ (Walter 1998; Pertermann and Hirschmann 2003). It is also known that partial melting of pyroxenite can produce an alkalic-to-tholeiitic transition in OIBs (Hirschmann et al. 2003; Keshav et al. 2004). Thus, high $\mathrm{Fe} / \mathrm{Mn}$ ratios for the Tongde picritic dikes resulted, most likely, from partial melting of pyroxenites in the mantle source (Herzberg 2006; Sobolev et al. 2007). This is also consistent with the fact that most olivines from these rocks are significantly enriched in $\mathrm{Ni}$ and relatively depleted in $\mathrm{Mn}$ and $\mathrm{Ca}$ (table $\mathrm{A} 4$ ), suggesting predominant contribution of pyroxenites to the continental basalts (Sobolev et al. 2005, 2007).

Picrites and komatiites are unambiguous indicators of a hotter-, or deeper-, than-normal mantle source (Anderson 1994). Generally, in areas where a hotter mantle plume rises, as in many LIPs, the degree of melting would be relatively high, and the parental melt can be picritic (Campbell and Griffiths 1990; Chung and Jahn 1995; Herzberg and O'Hara 1998; Zhang et al. 2006). A melting degree of $\sim 20 \%$ for TBZ0600 was estimated using the PRIMELT2.XLS software (Herzberg and Asimow 2008). Therefore, melting for the Tongde picritic dikes appears to have occurred in a pyroxenitic source, with a melting degree of $\sim 20 \%$.

Tectonic Significance. Neoproterozoic magmatic rocks with ages of $860-750 \mathrm{Ma}$ are widespread along the western margin of the Yangtze Block. However, the origin and tectonic implications of these rocks are an issue of debate; that is, they are either related to mantle plume activities ( $\mathrm{Li}$ et al. $1995,1999,2003 c)$ or are of magmatic arc-related origin (Zhou et al. 2002a, 2006a, 2006b). Our new 
data for the ca. 800-Ma Tongde picritic dikes in the Yanbian area place new constraints on the Neoproterozoic tectonic evolution on the western margin of the Yangtze Block.

The Tongde picritic dikes exhibit characteristic incompatible-trace-element patterns comparable to those of OIB (fig. 6b). In the discrimination diagrams for Ti-Zr-Y (fig. A4a, available in the online edition or from the Journal of Geology office; Pearce and Cann 1973) and La/10-Y/15-Nb/8 (fig. $\mathrm{A} 4 b$; Cabanis and Lecolle 1989), these picritic rocks plot exclusively within the fields of within-plate basalt and continental basalts, indicating that they were formed in a continental rift. In addition, the clinopyroxenes from the picritic dikes are characterized by high $\mathrm{Ti}\left(\mathrm{TiO}_{2}\right.$ up to $\left.2.2 \%\right)$ and low $\mathrm{Al} /$ Ti ratios (fig. A5, available in the online edition or from the Journal of Geology office; Loucks 1990), typical of rift-related mafic-ultramafic intrusions. As mentioned above, these dikes exhibit no $\mathrm{Nb}$ and Ta depletion, in obvious contrast to mafic rocks generated in arc-related settings. These arguments clearly point toward a within-plate rift, rather than a continental-arc environment, for the formation of the Tongde picritic dikes.

In general, olivine with Fo $>90$ is a common feature of komatiites (e.g., Arndt et al. 1977; Lesher 1989). This type of olivine has also been reported in picritic rocks from several CFB provinces (e.g., Krishnamurthy et al. 2000; Larsen and Pedersen 2000; Thompson and Gibson 2000; Zhang et al. 2006) and OIBs (Garcia et al. 1995). We note that olivine phenocrysts with Fo values of $>90$ in the Tongde dikes contain $0.11 \%-0.42 \% \mathrm{CaO}$ and $0.09 \%-0.39 \% \mathrm{Cr}_{2} \mathrm{O}_{3}$ (fig. A3, available in the online edition or from the Journal of Geology office), clearly different from those in mantle peridotites or mantle xenoliths, which have much lower $\mathrm{Ca}$ and $\mathrm{Cr}$ (e.g., Gurenko et al. 1996; Thompson and Gibson 2000). Therefore, the picritic dikes in the Yanbian area are similar to many picritic rocks within continental LIPs of plume origin.

The ca. 800-Ma Tongde picritic dikes are broadly concurrent with the ca. 820-810-Ma Tiechuanshan-Bikou CFB (Ling et al. 2003; Wang et al. 2008), the ca. 810-Ma Suxiong bimodal volcanic rocks $(\mathrm{Li}$ et al. 2003b), and numerous ca. 790-760-Ma mafic dikes in the Kangding-Shimian and Yanbian areas
(Li et al. 2003c; Lin et al. 2007; Zhu et al. 2008), suggesting that extensive intraplate mafic magmatism occurred at ca. 820-760 Ma along the western to northwestern margin of the Yangtze Block. The genesis of these widespread mafic rocks can be best explained by the proposed mid-Neoproterozoic mantle superplume activity (Li et al. 2003c), which triggered variable degrees of partial melting of the OIB-like mantle sources and some metasomatized mantle sources (Zhao and Zhou 2007) by previous subduction processes during the Sibao orogenesis.

\section{Conclusions}

1. SIMS U-Pb zircon dating results indicate that the Tongde picritic dikes were emplaced at $796 \pm 5$ Ma.

2. These picritic dikes are characterized by highly positive $\varepsilon_{\mathrm{Nd}}(T)$ values $(6.9-8.7)$ and enrichment in most incompatible trace elements. The parental magmas of the dikes are high-Ti picritic melts that originated from $\sim 20 \%$ partial melting of a pyroxenitic source; thereafter, the magmas underwent further olivine accumulation and little crustal contamination.

3. The Tongde picritic dikes were derived from an anomalously hot mantle source with a potential temperature of $1600^{\circ}-1620^{\circ} \mathrm{C}$. They were formed in a mid-Neoproterozoic continental rift, most likely related to the proposed 830-750-Ma mantle superplume beneath South China within the Rodinia supercontinent.

\section{A C K N O W L E D G M E N T S}

We appreciate the assistance of G. F. Zhou, W. Q. Zheng, and S. R. Liu in electron microprobe analysis; Y. Liu, Q. L. Li, and H. Tao in SIMS dating; W. C. Su for CL images; C. X. Feng in major-element analyses; J. Hu and Y. R. Cai in trace-element analyses; and Z. Y. Chu and C. F. Li in Nd isotope analyses. The article has benefited from review comments of D. B. Rowley, G. Fitton, and E. Gazel. This work is jointly supported by the National Natural Science Foundation of China (grants 40673031, 40721063, and 40873028) and the Special Research Fund of the State Key Laboratory of Ore Deposit Geochemistry.

\section{R E F E R E N C E S C I T E D}

Albarède, F. 1992. How deep do common basaltic magmas form and differentiate? J. Geophys. Res. 97: 10,997-11,009.
Anderson, D. L. 1994. Komatiites and picrites: evidence that the "plume" source is depleted. Earth Planet. Sci. Lett. 128:303-311. 
Arndt, N. T.; Naldrett, A. J.; and Pyke, D. R. 1977. Komatiitic and iron-rich tholeiitic lavas of Munro Township, northeast Ontario. J. Petrol. 18:319-369.

Boynton, W. V. 1984. Geochemistry of the rare earth elements: meteorite studies. In Henderson, P., ed. Rare earth element geochemistry. Amsterdam, Elsevier, p. 63-114.

Cabanis, B., and Lecolle, M. 1989. Le diagramme La/10$\mathrm{Y} / 15-\mathrm{Nb} / 8$ : un outil pour la discrimination des séries volcaniques et la mise en évidence des processus de mélange et/ou de contamination crustale. C. R. Acad. Sci. Ser. II 309:2023-2029.

Campbell, I. H., and Griffiths, R. W. 1990. Implications of mantle plume structure for the evolution of flood basalts. Earth Planet. Sci. Lett. 99:79-63.

Chung, S. L., and Jahn, B. M. 1995. Plume-lithosphere interaction in generation of the Emeishan flood basalts at the Permian-Triassic boundary. Geology 23: 889-892.

Cong, B. L. 1988. Formation and evolution of Panxi paleorift. Science Press, Beijing (in Chinese).

Garcia, M. O.; Hulsebosch, T. P.; and Rhodes, J. M. 1995. Olivine-rich submarine basalts from the Southwest Rift Zone of Mauna Loa volcano: implications for magmatic processes and geochemical evolution. In Rhodes, J. M., and Lockwood, J. P., eds. Mauna Loa revealed: structure, composition, history, and hazards. Am. Geophys. Union Geophys. Monogr. 92:219-239.

Greentree, M. R.; Li, Z. X.; Li, X. H.; and Wu, H. C. 2006. Late Mesoproterozoic to earliest Neoproterozoic basin record of the Sibao orogenesis in western South China and relationship to the assembly of Rodinia. Precambrian Res. 151:79-100.

Gurenko, A. A.; Hansteen, T. H.; and Schmincke, H. U. 1996. Evolution of parental magmas of Miocene shield basalts of Gran Canaria (Canary Islands): constraints from crystal, melt and fluid inclusions in minerals. Contrib. Mineral. Petrol. 124:422-435.

Herzberg, C. 2006. Petrology and thermal structure of the Hawaiian plume from Mauna Kea volcano. Nature 444:605-609.

Herzberg, C., and Asimow, P. D. 2008. Petrology of some oceanic island basalts: PRIMELT2.XLS software for primary magma calculation. Geochem. Geophys. Geosyst. 9:Q09001, doi:10.1029/2008GC002057.

Herzberg, C.; Asimow, P. D.; Arndt, N.; Niu, Y.; Lesher, C. M.; Fitton, J. G.; and Saunders, A. D. 2007. Temperature in ambient mantle and plumes: constraints from basalts, picrites, and komatiites. Geochem. Geophys. Geosyst. 8:Q02006, doi:10.1029/2006GC001390.

Herzberg, C., and O'Hara, M. J. 1998. Phase equilibrium constraints on the origin of basalts, picrites, and komatiites. Earth Sci. Rev. 44:39-79.

Hirschmann, M. M.; Kogiso, T.; Baker, M.; and Stolper, E. M. 2003. Alkalic magmas generated by partial melting of garnet pyroxenite. Geology 31:481-484.

Humayun, M.; Qin, L.; and Norman, M. D. 2004. Geochemical evidence for excess iron in the mantle beneath Hawaii. Science 306:91-94.

Keshav, S.; Gudfinnsson, G. H.; Sen, G.; and Fei, Y. W.
2004. High-pressure melting experiments on garnet clinopyroxenite and the alkalic to tholeiitic transition in ocean island basalts. Earth Planet. Sci. Lett. 223: 365-379.

Krishnamurthy, P.; Gopalan, K.; and MacDougall, J. D. 2000. Olivine compositions in picrite basalts and the Deccan volcanic cycle. J. Petrol. 41:1057-1069.

Langmuir, C. H.; Klein, E. M.; and Plank, T. 1992. Petrological systematics of mid-ocean ridge basalts: constraints on melt generation beneath ocean ridges. In Morgan, J. P.; Blackman, D. K.; and Sinton, J. M., eds. Mantle flow and melt generation at mid-ocean ridges. Am. Geophys. Union Geophys. Monogr. 71:183-280.

Larsen, L. M., and Pedersen, A. K. 2000. Processes in high-Mg, high- $T$ magmas: evidence from olivine, chromite and glass in Palaeogene picrites from West Greenland. J. Petrol. 41:1071-1098.

Le Bas, M. J. 2000. IUGS reclassification of the high-Mg and picritic volcanic rocks. J. Petrol. 41:1467-1470.

Lesher, C. M. 1989. Komatiite-associated nickel sulfide deposits. In Whitney, J. A., and Naldrett, A. J., eds. Ore deposition associated with magmas. Rev. Econ. Geol. 4:45-101.

Li, X. H.; Li, Z. X.; Ge, W.; Zhou, H. W.; Li, W. X.; Liu, Y.; and Wingate, M. T. T. 2003a. Neoproterozoic granitoids in South China: crustal melting above a mantle plume at ca. $825 \mathrm{Ma}$ ? Precambrian Res. 122:45-83.

Li, X. H.; Li, Z. X.; Sinclair, J. A.; Li, W. X.; and Carter, G. 2006. Revisiting the "Yanbian Terrane": implications for Neoproterozoic tectonic evolution of the western Yangtze Block, South China. Precambrian Res. 151:14-30.

Li, X. H.; Li, Z. X.; Zhou, H.; Liu, Y.; and Kinny, P. D. 2002a. U-Pb zircon geochronology, geochemistry and $\mathrm{Nd}$ isotopic study of Neoproterozoic bimodal volcanic rocks in the Kangding Rift of South China: implications for the initial rifting of Rodinia. Precambrian Res. 113:135-155.

Li, X. H.; Li, Z. X.; Zhou, H.; Liu, Y.; Liang, X. Y.; and Li, W. X. 2003b. SHRIMP U-Pb zircon age, geochemistry and $\mathrm{Nd}$ isotope of the Guandaoshan pluton in SW Sichuan: petrogenesis and tectonic significance. Sci. China (Ser. D) 46(suppl.):73-83.

Li, X. H.; Liu, Y.; Li, Q. L.; Guo, C. H.; and Chamberlain, K. R. 2009. Precise determination of Phanerozoic zircon $\mathrm{Pb} / \mathrm{Pb}$ age by multi-collector SIMS without external standardization. Geochem. Geophys. Geosyst. 10:Q04010, doi:10.1029/2009GC002400.

Li, Z. X.; Li, X. H.; Kinny, P. D.; and Wang, J. 1999. The breakup of Rodinia: did it start with a mantle plume beneath South China? Earth Planet. Sci. Lett. 173:171181.

Li, Z. X.; Li, X. H.; Kinny, P. D.; Wang, J.; Zhang, S.; and Zhou, H. 2003c. Geochronology of Neoproterozoic syn-rift magmatism in the Yangtze Craton, South China and correlations with other continents: evidence for a mantle superplume that broke up Rodinia. Precambrian Res. 122:85-109.

Li, Z. X.; Li, X. H.; Zhou, H.; and Kinny, P. D. $2002 b$. Grenvillian continental collision in South China: new 
SHRIMP U-Pb zircon results and implications for the configuration of Rodinia. Geology 30:163-166.

Li, Z. X.; Zhang, L.; and Powell, C. M. 1995. South China in Rodinia: part of the missing link between Australia-East Antarctica and Laurentia? Geology 23:407410.

Lin, G. C.; Li, X. H.; and Li, W. X. 2007. SHRIMP U-Pb zircon age, geochemistry and Nd-Hf isotope of Neoproterozoic mafic dyke swarms in western Sichuan: petrogenesis and tectonic significance. Sci. China (Ser. D) 50:1-16.

Ling, W.; Gao, S.; Zhang, B.; Li, H.; Liu, Y.; and Cheng, J. 2003. Neoproterozoic tectonic evolution of the northwestern Yangtze craton, South China: implications for amalgamation and break-up of the Rodinia supercontinent. Precambrian Res. 122:111-140.

Loucks, R. R. 1990. Discrimination of ophiolitic from nonophiolitic ultramafic-mafic allochthons in orogenic belts by the $\mathrm{Al} / \mathrm{Ti}$ ratio in clinopyroxene. Geology 18:346-349.

Lugmair, G. W., and Harti, K. 1978. Lunar initial ${ }^{143} \mathrm{Nd} /$ ${ }^{144} \mathrm{Nd}$ : differential evolution of the lunar crust and mantle. Earth. Planet. Sci. Lett. 39:349-357.

McKenzie, D., and Bickle, M. J. 1988. The volume and composition of melt generated by extension of the lithosphere. J. Petrol. 29:625-679.

Paces, J. B., and Bell, K. 1989. Non-depleted sub-continental mantle beneath the Superior Province of the Canadian Shield: Nd-Sr isotopic and trace element evidence from midcontinent rift basalts. Geochim. Cosmochim. Acta 53:2023-2035.

Pearce, J. A., and Cann, J. R. 1973. Tectonic setting of basic volcanic rocks determined using trace element analysis. Earth Planet. Sci. Lett. 19:290-300.

Peate, D. W.; Hawkesworth, C. J.; and Mantovani, M. S. M. 1992. Chemical stratigraphy of the Paraná lavas (South America): classification of magma types and their spatial distribution. Bull. Volcanol. 55:119-139.

Pertermann, M., and Hirschmann, M. M. 2003. Partial melting experiments on a MORB-like pyroxenite between 2 and $3 \mathrm{GPa}$ : constraints on the presence of pyroxenite in basalt source regions from solidus location and melting rate. J. Geophys. Res. 108:2125, doi:10.1029/2000JB000118.

Pik, R.; Deniel, C.; Coulon, C.; Yirgu, G.; Hofmann, C.; and Ayalew, D. 1998. The northwestern Ethiopian plateau flood basalts: classification and spatial distribution of magma types. J. Volcanol. Geotherm. Res. 81: 91-111.

Pik, R.; Deniel, C.; Coulon, C.; Yirgu, G.; and Marty, B. 1999. Isotopic and trace element signatures of Ethiopian flood basalts: evidence for plume-lithosphere interaction. Geochim. Cosmochim. Acta 63:2263-2279.

Pollack, H. N. 1997. Thermal characteristics of the Archaean. In de Wit, M. J., and Ashwall, L. D., eds. Greenstone belts. Oxford Monogr. Geol. Geophys. 35: 223-232.

Putirka, K. D. 2005. Mantle potential temperatures at Hawaii, Iceland, and the mid-ocean ridge system, as inferred from olivine phenocrysts: evidence for ther- mally driven mantle plume: Geochem. Geophys. Geosyst. 6:Q05L08, doi: 1029/2005GC000915.

Qi, L.; Hu, J.; and Grégoire, D. C. 2000. Determination of trace elements in granites by inductively coupled plasma mass spectrometry. Talanta 51:507-513.

RGTCCT (Regional Geological Team, Chengdu College of Technology). 2000. The geological map (G47 E 008023) of the People's Republic of China, scale 1 : 50,000 (in Chinese).

Russell, J. K., and Nicholls, J. 1988. Analysis of petrologic hypotheses with Pearce element ratios. Contrib. Mineral. Petrol. 99:25-35.

SBG (Sichuan Bureau of Geology). 1972. A report of regional geological survey in Yanbian area of the People's Republic of China, scale 1 : 200,000 (in Chinese).

SBGMR (Sichuan Bureau of Geology and Mineral Resources). 1991. Regional geology of Sichuan Province. Beijing, Geology Publishing House, 730 pp. (in Chinese with English abstract).

Sinclair, J. A. 2001. A re-examination of the "Yanbian Ophiolite Suite": evidence for western extension of the Mesoproterozoic Sibao Orogen in South China. Geol. Soc. Aus. Abstr. 65:99-100.

Sobolev, A. V.; Hofmann, A. W.; Kuzmin, D. V.; Yaxley, G. M.; Arndt, N. T.; Chung, S.-L.; Danyushevsky, L. V.; et al. 2007. The amount of recycled crust in sources of mantle-derived melts. Science 316:412-417.

Sobolev, A. V.; Hofmann, A. W.; Sobolev, S. V.; and Nikogosian, I. K. 2005. An olivine-free mantle source of Hawaiian shield basalts. Nature 434:590-597.

Stacey, J. S., and Kramers, J. D. 1975. Approximation of terrestrial lead isotope evolution by a two-stage model. Earth Planet. Sci. Lett. 26:207-221.

Stewart, K., and Rogers, N. 1996. Mantle plume and lithosphere contributions to basalts from southern Ethiopia. Earth Planet. Sci. Lett. 139:195-211.

Sun, C. M., and Vuagnat, M. 1992. Proterozoic ophiolites from Yanbian and Shimian (Sichuan Province, China): petrography, geochemistry, petrogenesis, and geotectonic environment. Schweiz. Mineral. Petrogr. Mitt. 72:389-413.

Sun, S.-S., and McDonough, W. F. 1989. Chemical and isotopic systematics of oceanic basalts: implications for mantle composition and processes. In: Saunders, A. D., and Norry, M. J., eds. Magmatism in the ocean basins. Geol. Soc. Lond. Spec. Publ. 42:313-345.

Sun, W. H.; Zhou, M. F.; Yan, D. P.; Li, J. W.; and Ma, Y. X. 2008. Provenance and tectonic setting of the Neoproterozoic Yanbian Group, western Yangtze Block (SW China). Precambrian Res. 167:213-236.

Sun, W. H.; Zhou, M. F.; and Zhao, J. H. 2007. Geochemistry and tectonic significance of basaltic lavas in the Neoproterozoic Yanbian Group, southern Sichuan Province, southwest China. Int. Geol. Rev. 49:554571.

Thompson, R. N., and Gibson, S. A. 2000. Transient high temperatures in mantle plume heads inferred from magnesian olivines in Phanerozoic picrites. Nature 407:502-506.

Thompson, R. N.; Gibson, S. A.; Dickin, A. P.; and Smith, 
P. M. 2001. Early Cretaceous basalt and picrite dykes of the southern Etendeka region, NW Namibia: windows into the role of the Tristan mantle plume in Paraná-Etendeka magmatism. J. Petrol. 42:2049-2081.

Tsikouras, B.; Pe-Piper, G.; Piper, D. J. W.; and Hatzipanagiotou, K. 2008. Triassic rift-related komatiite, picrite and basalt, Pelagonian continental margin, Greece. Lithos 104:199-215.

Walter, M. J. 1998. Melting of garnet peridotite and the origin of komatiite and depleted lithosphere. J. Petrol. 39, 29-60.

Wang, J., and Li, Z. X. 2003. History of Neoproterozoic rift basins in South China: implications for Rodinia break-up. Precambrian Res. 122:141-158.

Wang, X. C.; Li, X. H.; Li, W. X.; and Li, Z. X. 2007. Ca. $825 \mathrm{Ma}$ komatiitic basalts in South China: first evidence for $>1500^{\circ} \mathrm{C}$ mantle melts by a Rodinian mantle plume. Geology 35:1103-1106.

Wang, X. C.; Li, X. H.; Li, W. X.; Li, Z. X.; Liu, Y.; Yang, Y. H.; Liang, X. R.; and Tu, X. L. 2008. The Bikou basalts in northwestern Yangtze Block, South China: remains of $820-810 \mathrm{Ma}$ continental flood basalts? GSA Bull. 120:1478-1492.

Wiedenbeck, M.; Allé, P.; Corfu, F.; Griffin, W. L.; Meier, M.; Oberli, F.; Von Quadt, A.; Roddick, J. C.; and Spiegel, W. 1995. Three natural zircon standards for U-Th$\mathrm{Pb}, \mathrm{Lu}-\mathrm{Hf}$, trace element and REE analyses. Geostand. Newsl. 19:1-23.

Winchester, J. A., and Floyd, P. A. 1976. Geochemical magma type discrimination: application to altered and metamorphosed igneous rocks. Earth Planet. Sci. Lett. 45:326-336.

Xu, Y. G.; Chung, S. L.; Jahn, B. M.; and Wu, G. Y. 2001. Petrologic and geochemical constraints on the petrogenesis of Permian-Triassic Emeishan flood basalts in southwestern China. Lithos 58:145-168.

Zhang, Z. C.; Mahoney, J. J.; Mao, J. W.; and Wang, F. S. 2006. Geochemistry of picritic and associated basalt flows of the western Emeishan flood basalt province, China. J. Petrol. 47:1997-2019.

Zhao J. H., and Zhou, M. F. 2007. Geochemistry of Neoproterozoic mafic intrusions in the Panzhihua district (Sichuan Province, SW China): implications for sub- duction-related metasomatism in the upper mantle. Precambrian Res. 152:27-47.

Zhou, H. W.; Li, X. H.; Wang, H. R.; Li, J.; and Li, H. M. 2002a. U-Pb zircon geochronology of basic volcanic rocks within the Yingyangguan Group in Hezhou, Guangxi, and its tectonic implications. Geol. Rev. 48: 22-25 (in Chinese with English abstract).

Zhou, J. B.; Li, X. H.; Ge, W.; and Li, Z. X. 2007. Age and origin of middle Neoproterozoic mafic magmatism in southern Yangtze Block and relevance to the breakup of Rodinia. Gondwana Res. 12:184-197.

Zhou, M. F.; Ma, Y. X.; Yan, D. P.; Xia, X. P.; Zhao, J. H.; and Sun, M. 2006a. The Yanbian terrane (southern Sichuan Province, SW China): a Neoproterozoic arc assemblage in the western margin of the Yangtze Block. Precambrian Res. 144:19-38.

Zhou, M. F.; Yan, D. P.; Kennedy, A. K.; Li, Y.; and Ding, J. 2002b. SHRIMP U-Pb zircon geochronological and geochemical evidence for Neoproterozoic arc-magmatism along the western margin of the Yangtze Block, South China. Earth Planet. Sci. Lett. 196:5167.

Zhou, M. F.; Yan, D. P.; Wang, C. L.; Qi, L.; and Kennedy, A. 2006b. Subduction-related origin of the $750 \mathrm{Ma}$ Xuelongbao adakitic complex (Sichuan Province, China): implications for the tectonic setting of the giant Neoproterozoic magmatic event in South China. Earth Planet. Sci. Lett. 248:271-285.

Zhu, W. G.; Zhong, H.; Deng, H. L.; Wilson, A. H.; Liu, B. G.; Li, C. Y.; and Qin, Y. 2006. SHRIMP zircon U$\mathrm{Pb}$ age, geochemistry and $\mathrm{Nd}-\mathrm{Sr}$ isotopes of the Gaojiacun mafic-ultramafic intrusive complex, SW China. Int. Geol. Rev. 48:650-668.

Zhu, W. G.; Zhong, H.; Li, X. H.; Deng, H. L.; He, D. F.; Wu, K. W.; and Bai, Z. J. 2008. SHRIMP zircon U-Pb geochronology, elemental, and $\mathrm{Nd}$ isotopic geochemistry of the Neoproterozoic mafic dykes in the Yanbian area, SW China. Precambrian Res. 164:66-85.

Zhu, W. G.; Zhong, H.; Li, X. H.; Liu, B. G.; Deng, H. L.; and Qin, Y. 2007. ${ }^{40} \mathrm{Ar}-{ }^{39} \mathrm{Ar}$ age, geochemistry and Sr$\mathrm{Nd}-\mathrm{Pb}$ isotopes of the Neoproterozoic Lengshuiqing $\mathrm{Cu}-\mathrm{Ni}$ sulfide-bearing mafic-ultramafic complex, SW China. Precambrian Res. 155:98-124. 